\title{
Short communication: Effect of corn planting population on phosphorus concentration and uptake in corn silage
}

\author{
G. Ferreira* and C. L. Teets \\ Department of Dairy Science, Virginia Tech, Blacksburg 24061
}

\section{ABSTRACT}

Greater utilization of nutrients reduces the potential runoff of nutrients to bodies of water. The objective of this study was to determine the concentration of $\mathrm{P}$ in corn biomass to estimate the removal of $\mathrm{P}$ from the soil when planting corn at different population levels. Whole-plant corn samples were collected during an onfarm research project conducted previously. The study included 7 different growing and harvesting conditions. In each cornfield, corn was planted in plots at a theoretical seeding rate of 55,000,70,000, 85,000, and 100,000 seeds/ha. Each seeding rate had 4 replicates within each field. At harvesting time, 5 consecutive plants from the 2 center rows and at 2 randomly selected spots within each plot were cut by hand at $15 \mathrm{~cm}$ above ground. Whole plants were weighed and chopped. After mixing thoroughly, a sample of the chopped material was placed in a bag, immediately placed in a cooler with dry ice, and transferred to the laboratory for storage. After thawing and drying, samples were ground and analyzed for P concentration. Single plant biomass and the number of standing plants at harvesting were used to determine dry matter yield. Total extraction of $\mathrm{P}$ was estimated as the product between plant biomass and $\mathrm{P}$ concentration. All variables were analyzed using a statistical model that included the effects of field, planting population, planting population nested within field, and random residual error. The concentration of $\mathrm{P}$ in the corn plant was greatest for 55,000 and 70,000 plants/ha (0.250\% dry matter) and least for 85,000 and 100,000 plants/ha $(0.235 \%$ dry matter $)$, whereas the uptake of $\mathrm{P}$ through the harvested biomass increased when corn planting population increased. In conclusion, increasing the planting population of corn for silage can increase $\mathrm{P}$ uptake from the soil, therefore reducing the potential runoff of $\mathrm{P}$ to bodies of water.

Received July 30, 2018.

Accepted October 31, 2018.

*Corresponding author: gonf@vt.edu
Key words: phosphorus, corn silage, planting population, nutrient management plan

\section{Short Communication}

To reduce the load of $\mathrm{N}$ and $\mathrm{P}$ in bodies of water, dairy farms are encouraged or mandated to develop nutrient management plans (Bosch et al., 2006; DCR, 2014). In dairy farming systems, 3 types of practices are used to reduce nutrient upload in bodies of water: (1) reducing nutrient excretion in manure, so it reduces its load on the soil, (2) reducing the amount and changing the fertilization method or timing of application to reduce nutrient runoff, and (3) reducing the potential of nutrient runoff to surface water (Dou et al., 2001; Bosch et al., 2006). The use of stream buffers, conservation tillage, and cover crops are common means to reduce nutrient runoff. The purpose of these practices is to increase the utilization of nutrients, while keeping them above ground, therefore reducing the potential of surface runoff and runoff through underground water (Powell et al., 2008).

Several studies reported that increasing the corn planting population can increase corn silage yields. $\mathrm{Cu}-$ sicanqui and Lauer (1999) reported that the greatest DM yield was obtained when corn plant density was increased to approximately 98,000 plants/ha. Ferreira et al. (2014) reported that forage yields increased linearly and by $41 \%$ when plant density was increased from 60,000 to 90,000 plants/ha. In another recent on-farm study, Ferreira and Teets (2017) also reported higher forage yields when corn planting population was increased from 55,000 to 100,000 plants/ha. In addition to the increased yields, the latter studies (Ferreira et al., 2014; Ferreira and Teets, 2017) reported similar nutrient composition of the forages obtained when corn was planted at different planting densities.

Increasing forage yields while maintaining nutritional quality of the forage has major environmental implications, as there is an increased retention of nutrients above ground when increasing the planting population. For example, data from Ferreira and Teets (2017) show that $\mathrm{N}$ uptake through corn silage was increased when 
corn planting population was increased from 55,000 to 100,000 plants/ha. In addition to suggesting a greater nutrient efficiency use, this outcome indicates that the potential of $\mathrm{N}$ runoff to bodies of water can be reduced by increasing planting population of corn for silage (Bosch et al., 2006).

Control of water runoff and erosion refers to practices that reduce the potential for $\mathrm{P}$ delivery to bodies of water (Bosch et al., 2006). Whether increasing the corn planting population increases $\mathrm{P}$ uptake from the soil, and therefore can reduce $\mathrm{P}$ runoff to bodies of water, has not been reported (Ferreira et al., 2014; Ferreira and Teets, 2017). We hypothesized that increasing the corn planting population increases $\mathrm{P}$ uptake from the soil through corn silage. Therefore, the objective of this study was to determine the concentration of $\mathrm{P}$ in corn biomass to estimate the removal of $\mathrm{P}$ from the soil when planting corn at different population levels.

Whole-plant corn samples were collected during an on-farm research project conducted previously (Ferreira and Teets, 2017) during the spring and summer seasons of 2014 and 2015 at 2 commercial dairy farms located in Museville (farm 1) and Gordonsville (farm 2), Virginia. The study included 7 different growing and harvesting conditions (described in Ferreira and Teets, 2017), hereafter called fields. In each field, corn was planted in plots (6-row width by 25 -m length) at a theoretical seeding rate of $55,000,70,000,85,000$, and 100,000 seeds/ha. The study was designed as a completely randomized design with 4 replicates for each of the 4 seeding rates within each field. Crop maturity at harvesting times differed among fields but not within fields. At harvesting time, 5 consecutive plants from the 2 center rows and at 2 randomly selected spots within each plot (i.e., 10 plants per plot) were cut by hand at $15 \mathrm{~cm}$ above ground. Whole plants were weighed and chopped with a Stanley CH2 wood chipper (GXi Outdoor Power LLC, Clayton, NC). After mixing thoroughly within a barrel, a sample of the chopped material was placed in a bag, immediately placed in a cooler with dry ice, and transferred to the laboratory for storage at $-20^{\circ} \mathrm{C}$. Chopped samples were thawed and dried at $55^{\circ} \mathrm{C}$ in a forced-air drying oven (Freas 645, Thermo Electron Corporation, Marietta, $\mathrm{OH}$ ) until constant weight. The resulting DM concentration was used to calculate DM yield. The dried sample was then ground to pass through a 1-mm screen of a cyclone mill (Udy Corporation, Fort Collins, CO) and analyzed for $\mathrm{P}$ concentration (method 965.17; AOAC International, 2000). Single plant biomass and the number of standing plants at harvesting were used to determine DM yield. For this, the number of plants within a 13.2$\mathrm{m}$ row was counted in 2 adjacent rows. This procedure was performed in each of the 16 plots from each of the cornfields. Total extraction of $\mathrm{P}(\mathrm{kg} / \mathrm{ha})$ was estimated as the product between plant biomass ( $\mathrm{kg}$ of $\mathrm{DM} / \mathrm{ha}$ ) and $\mathrm{P}$ concentration $(\% \mathrm{DM})$. All variables were analyzed using the MIXED procedure of SAS (version 9.4, SAS Institute Inc., Cary, NC). The statistical model included the effects of field (fixed; df $=6$ ), planting population (fixed; df $=3$ ), planting population nested within field (fixed; $d f=18$ ), and the random residual error. Comparisons between treatment least squares means were tested using the PDIFF option of SAS.

The concentration of $\mathrm{P}$ in the corn plant (Figure 1) was greatest $(P<0.01)$ for 55,000 and 70,000 plants/ha $(0.250 \% \mathrm{DM})$ and least for 85,000 and 100,000 plants/ ha $(0.235 \% \mathrm{DM})$, whereas the uptake of $\mathrm{P}$ through the harvested biomass increased $(P<0.01)$ when the corn planting population increased (Figure 2). The concentration of $\mathrm{P}$ is typically greater in grains than in hays or silages (NRC, 2001). In this study, the number of kernels per plant decreased linearly when planting density was increased (Ferreira and Teets, 2017). Therefore, we attribute the reduced concentration of $\mathrm{P}$ to a decreased number of kernels in the whole plant.

The results of this study have several implications. First, and in agreement with our hypothesis, increasing the planting population of corn for silage can increase $\mathrm{P}$ uptake from the soil, therefore reducing the potential runoff of $\mathrm{P}$ to bodies of water. Second, increasing the planting population of corn for silage can decrease the concentration of $\mathrm{P}$ in corn silage. This lower concentration of $\mathrm{P}$ in corn silage might help in formulating diets

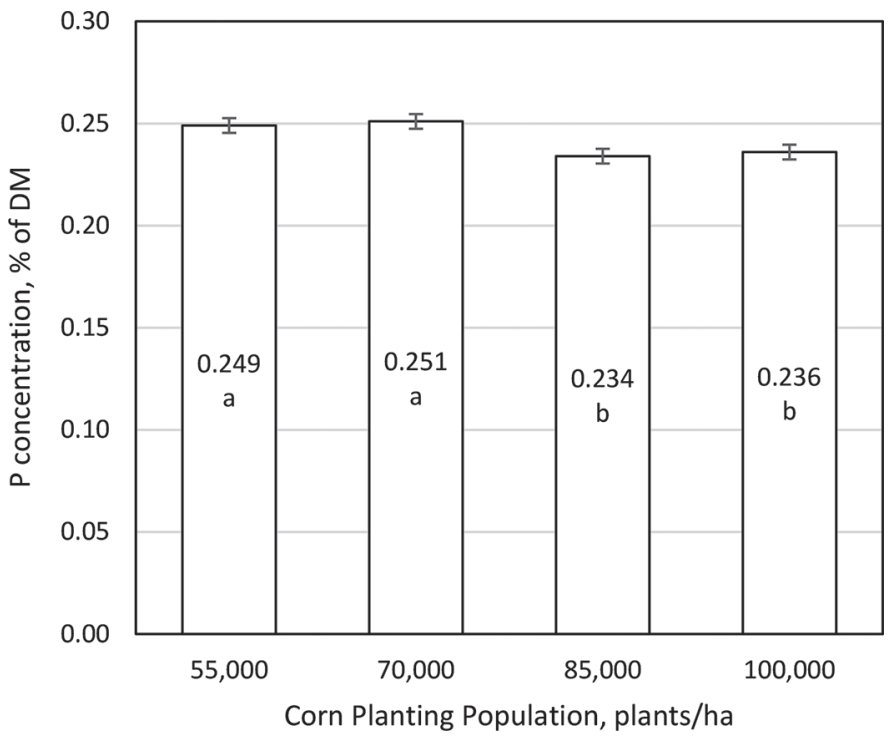

Figure 1. Effect of corn planting population on $\mathrm{P}$ concentration (\% of DM) of whole-plant corn for silage. Corn was planted in plots at a theoretical seeding rate of $55,000,70,000,85,000$, and 100,000 seeds/ ha $(\mathrm{SEM}=0.036)$. Columns with different letters differ $(P<0.05)$. 


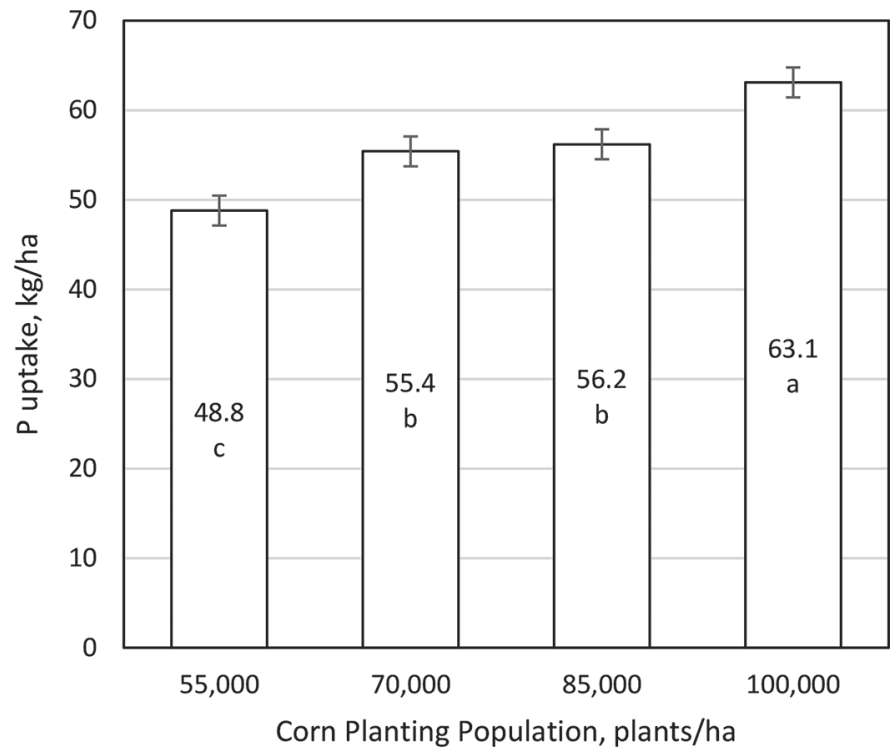

Figure 2. Effect of corn planting population on $\mathrm{P}$ uptake from the soil ( $\mathrm{kg}$ of $\mathrm{P} / \mathrm{ha}$ ) through whole-plant corn harvested for silage. Corn was planted in plots at a theoretical seeding rate of $55,000,70,000$, 85,000 , and 100,000 seeds $/$ ha $(\mathrm{SEM}=1.67)$. Columns with different letters differ $(P<0.05)$.

with lower concentrations of $\mathrm{P}$, which could help reduce $\mathrm{P}$ excretion in manure and reduce $\mathrm{P}$ loads on the soil, therefore reducing potential $\mathrm{P}$ runoff to bodies of water. Finally, many dairy farmers cannot grow enough forage to reach the following harvesting season. This obligates dairy farmers to import feeds into the farm, quite often at high prices. Feed imports very likely result in increased nutrient mass balances, which increase the likelihood of nutrient buildup and runoff losses (Dou et al., 2001; Bosch et al., 2006). Therefore, through greater biomass yields and $\mathrm{P}$ uptake from the soil, increasing the corn planting population may have great relevance in ensuring economic and environmental sustainability of dairy farm operations (von Keyserlingk et al., 2013).

\section{ACKNOWLEDGMENTS}

We are extremely thankful to dairy farmers Nathan and Paul Hammock (Pittsylvania County, VA) and Phillip and Coty Goodwin (Orange County, VA) for collaborating with this on-farm study. This project was funded in part by the Southern Sustainable Agriculture Research and Education On-farm Research Program (Integrating Cropping Practices to Improve Nutrient Management Plans and Ensure Environmental and Economic Sustainability in Dairy Farming Systems), USDA-NIFA Hatch Project VA-160025, and USDA-NIFA Multistate Project VA-136291 (NC-2042, Management Systems to Improve the Economic and Environmental Sustainability of Dairy Enterprises).

\section{REFERENCES}

AOAC International. 2000. Official Methods of Analysis. 17th ed. AOAC International, Gaithersburg, MD.

Bosch, D. J., M. L. Wolfe, and K. F. Knowlton. 2006. Reducing phosphorus runoff from dairy farms. J. Environ. Qual. 35:918-927.

Cusicanqui, J. A., and J. G. Lauer. 1999. Plant density and hybrid influence on corn forage yield and quality. Agron. J. 91:911-915.

DCR. 2014. Virginia Nutrient Management Standards and Criteria. Department of Conservation and Recreation, Richmond, VA.

Dou, Z., D. T. Galligan, C. F. Ramberg Jr., C. Meadows, and J. D. Ferguson. 2001. A survey of dairy farming in Pennsylvania: Nutrient management practices and implications. J. Dairy Sci. 84:966-973.

Ferreira, G., D. Carp, M. Alfonso, and S. Depino. 2014. Effect of planting density on nutritional quality of green-chopped corn for silage. J. Dairy Sci. 97:5918-5921.

Ferreira, G., and C. L. Teets. 2017. Effect of planting density on yield, nutritional quality, and ruminal in vitro digestibility of corn for silage grown under on-farm conditions. Prof. Anim. Sci. 33:420-425.

NRC. 2001. Nutrient Requirements of Dairy Cattle. 7th rev. ed. National Academies Press, Washington, DC.

Powell, J. M., Y. Li, Z. Wu, G. A. Broderick, and B. J. Holmes. 2008. Rapid assessment of feed and manure nutrient management on confinement dairy farms. Nutr. Cycl. Agroecosyst. 82:107-115.

von Keyserlingk, M. A., N. P. Martin, E. Kebreab, K. F. Knowlton, R. J. Grant, M. Stephenson, C. J. Sniffen, J. P. Harner 3rd, A. D. Wright, and S. I. Smith. 2013. Invited review: Sustainability of the US dairy industry. J. Dairy Sci. 96:5405-5425. 